\title{
Synthesis, Characterization, Theoretical Crystal Structure, and Antibacterial Activities of Some Transition Metal Complexes of the Thiosemicarbazone (Z)-2-(pyrrolidin- 2-ylidene)hydrazinecarbothioamide
}

\author{
Ahmed A. Al-Amiery, ${ }^{1,2}$ Yasmien K. Al-Majedy, ${ }^{1}$ Haziem Abdulreazak, ${ }^{3}$ and Hussain Abood ${ }^{1}$ \\ ${ }^{1}$ Biotechnology Division, Applied Science Department, University of Technology, Baghdad 10066, Iraq \\ ${ }^{2}$ Department of Chemical and Processing Engineering, Faculty of Engineering and Built Environment, \\ University of Kebangsaan Malaysia, Bangi, Selangor 43600, Malaysia \\ ${ }^{3}$ Chemistry Department, College of Science, Al Koofa University, Al Koofa 54003, Iraq
}

Correspondence should be addressed to Ahmed A. Al-Amiery, dr.ahmed1975@gmail.com

Received 1 April 2011; Accepted 3 June 2011

Academic Editor: Lorenzo Pellerito

Copyright (c) 2011 Ahmed A. Al-Amiery et al. This is an open access article distributed under the Creative Commons Attribution License, which permits unrestricted use, distribution, and reproduction in any medium, provided the original work is properly cited.

Problem Statement. In Iraq like most third world countries, attempts discovered new antibiotic drugs derived from thiosemicarbazide and its metal complexes and developed the branch of applied in organic chemistry. Approach. New (Z)-2-(pyrrolidin2-ylidene)hydrazinecarbothioamide (L) was synthesized in a good yield by the reaction of pyrrolidone with thiosemicarbazide. $\mathrm{Co}(\mathrm{II}), \mathrm{Ni}(\mathrm{II})$, and $\mathrm{Cu}(\mathrm{II})$ complexes of (L) were prepared and characterized by FT-IR, UV/visible spectra, ${ }^{1} \mathrm{HNMR}$, and CHN analyses. Moreover, charge, bond length, bond angle, twist angle, heat of formation, and steric energy were calculated by using of the ChemOffice program, and the DFT calculations for the complexes were done. The free ligand and its metal complexes were tested in vitro against several microorganisms (Staphylococcus aurous, E. coli, Proteus vulgaris, Pseudomonas, and Klebsiella pneumoniae) to assess their antimicrobial properties. Results. The study shows that these complexes have octahedral geometry; in addition, it has high activity against tested bacteria. Conclusion/Recommendations. Based on the reported results, it may be concluded that ligand acts as bidentate, neutral ligand, coordinating through one of the nitrogen and sulfur atoms.

\section{Introduction}

The chemistry of thiosemicarbazones has received considerable attention because of their variable bonding modes, promising biological implications, structural diversity, and ion-sensing ability [1-3]. They have been used as drugs and are reported to possess a wide variety of biological activities against bacteria, fungi, and certain type of tumors, and they are also a useful model for bioinorganic processes [4-6]. The activity of these compounds is strongly dependent on the nature of the heteroatomic ring and the position of attachment to the ring as well as the form of thiosemicarbazone moiety [7]. These are studied extensively due to their flexibility, selectivity, and sensitivity towards the central metal atom, and structural similarities with natural biological substances, and due to the presence of imine group $(-\mathrm{N}=\mathrm{CH}-)$ which imparts the biological activity [8-12]. There is no report on the complexes of (Z)-2-(pyrrolidin2-ylidene)hydrazinecarbothioamide (L). We now present details of the complexes of (L) with cobalt(II), nickel(II), and copper(II) ion.

\section{Materials and Methods}

2.1. General. All chemicals used were of reagent grade (supplied by either Merck or Fluka) and used as supplied. The FTIR spectra in the range $(4000-200) \mathrm{cm}^{-1}$ were recorded as cesium iodide disc on FTIR 8300 Shimadzu Spectrophotometer. Proton NMR spectra were recorded on Bruker-DPX $300 \mathrm{MHz}$ spectrometer with TMS as internal 
TABle 1: Conductivity, colors, and elemental analysis data of the complexes.

\begin{tabular}{|c|c|c|c|c|c|c|c|c|c|c|}
\hline \multirow{2}{*}{ NO. } & \multirow{2}{*}{ Complex } & \multirow{2}{*}{ Yield \% } & \multirow{2}{*}{ M.P. ${ }^{\circ} \mathrm{C}$} & \multicolumn{4}{|c|}{ Analysis: Found (cal.) \% } & \multirow{2}{*}{$M: L$} & \multirow{2}{*}{ Color } & \multirow{2}{*}{$\begin{array}{l}\Omega \mathrm{m} \mathrm{ohm} \\
\mathrm{cm}^{2} \mathrm{~mol}^{-1}\end{array}$} \\
\hline & & & & Metal & $\mathrm{C}$ & $\mathrm{H}$ & $\mathrm{N}$ & & & \\
\hline $\mathrm{C} 1$ & $\mathrm{Co}\left(\mathrm{C}_{5} \mathrm{H}_{10} \mathrm{~N}_{4} \mathrm{~S}\right)_{2} \mathrm{Cl}_{2}$ & 75 & Over 300 & $13.21(12.7)$ & $24.91(26.4)$ & $4.52(4.22)$ & $24.11(24.87)$ & $1: 2$ & Dark brown & 30 \\
\hline $\mathrm{C} 2$ & $\mathrm{Ni}\left(\mathrm{C}_{5} \mathrm{H}_{10} \mathrm{~N}_{4} \mathrm{~S}\right)_{2} \mathrm{Cl}_{2}$ & 60 & Over 300 & $13.16(12.65)$ & $23.93(25.12)$ & $4.52(4.12)$ & $25.12(24.16)$ & $1: 2$ & Light green & 65 \\
\hline $\mathrm{C} 3$ & $\mathrm{Cu}\left(\mathrm{C}_{5} \mathrm{H}_{10} \mathrm{~N}_{4} \mathrm{~S}\right)_{2} \mathrm{Cl}_{2}$ & 77 & 260 & $14.09(13.39)$ & $23.64(25.94)$ & $4.47(4.30)$ & $23.85(24.43)$ & $1: 2$ & Green & 30 \\
\hline
\end{tabular}

TABLe 2: Infrared absorption frequencies $\left(\mathrm{cm}^{-1}\right)$ of $\mathrm{Co}(\mathrm{II}), \mathrm{Ni}(\mathrm{II})$, and $\mathrm{Cu}(\mathrm{II})$ complexes.

\begin{tabular}{|c|c|c|c|c|c|c|c|c|}
\hline Compounds & $v(\mathrm{~N}-\mathrm{H})$ & $v(\mathrm{C}=\mathrm{N})$ & $v(\mathrm{C}-\mathrm{N})$ & $\nu(\mathrm{N}-\mathrm{N})$ & $\nu(\mathrm{C}=\mathrm{S})$ & $v(\mathrm{M}-\mathrm{N})$ & $\mathrm{v}(\mathrm{M}-\mathrm{S})$ & $\mathrm{v}(\mathrm{M}-\mathrm{Cl})$ \\
\hline Ligand & $3395 \mathrm{~s}, 3275 \mathrm{~s}$ & $1600 \mathrm{~s}$ & $1330 \mathrm{~s}, 1200 \mathrm{~m}$ & $1035 \mathrm{~m}$ & $855 \mathrm{~s}, 770 \mathrm{~s}$ & - & - & - \\
\hline $\mathrm{C} 1$ & $3330 \mathrm{~m}, 3265 \mathrm{~m}$ & $1570 \mathrm{~s}$ & $1380 \mathrm{~s}, 1240 \mathrm{~m}$ & $1075 \mathrm{~m}$ & $850 \mathrm{~s}, 780 \mathrm{~m}$ & $525 \mathrm{~m}$ & $440 \mathrm{~m}$ & $350 \mathrm{w}$ \\
\hline $\mathrm{C} 2$ & $3320 \mathrm{~m}, 3260 \mathrm{~m}$ & $1565 \mathrm{~s}$ & $1380 \mathrm{~s}, 1235 \mathrm{~m}$ & $1070 \mathrm{~m}$ & $835 \mathrm{~s}, 780 \mathrm{~m}$ & $535 \mathrm{~m}$ & $420 \mathrm{~m}$ & $355 \mathrm{w}$ \\
\hline $\mathrm{C} 3$ & $3385 \mathrm{~m}, 3275 \mathrm{~m}$ & $1575 \mathrm{~s}$ & $1365 \mathrm{~s}, 1240 \mathrm{~m}$ & $1060 \mathrm{~m}$ & $840 \mathrm{~s}, 795 \mathrm{~m}$ & $520 \mathrm{~m}$ & $430 \mathrm{~m}$ & $360 \mathrm{~m}$ \\
\hline
\end{tabular}

standard. The UV-Visible spectra were measured in ethanol using Shimadzu UV-Vis. 160 A spectrophotometer in the range (200-1000) nm. Magnetic susceptibility measurement for complexes was obtained at room temperature using (magnetic susceptibility balance model MSB-MKI). Flame atomic absorption of elemental analyzer, shimadzu AA-670, was used for metal determination. Elemental microanalysis, was carried out using C.H.N elemental analyzer model 5500-Carlo Erba instrument. Gallen Kamp M.F.B.600.010 F melting point apparatus was used to measure the melting point of all the prepared compounds.

\subsection{Synthesis of (Z)-2-(pyrrolidin-2-ylidene)hydrazinecarbo-} thioamide $(L)$. Pyrrolidone $(10 \mathrm{mmol})$ in hot ethanol $(20 \mathrm{~mL})$ was mixed with hot ethanolic solution of thiosemicarbazide $(10 \mathrm{mmol})$. The mixture was refluxed for 6 hours on a water bath; on cooling the contents, the precipitate was separated out, filtered washed with $50 \%$ cold ethanol, and dried in vacuum over $\mathrm{P}_{4} \mathrm{O}_{10}$, melting point of $176^{\circ} \mathrm{C}$ and yield of $73 \%$ of yellow crystal (Z)-2-(pyrrolidin-2ylidene)hydrazinecarbothioamide. The proposed structure can be shown according to Scheme 1 .

Proton NMR (1.4 t $(2 \mathrm{H})$ for $\mathrm{CH}_{2}$, m. 2.0(2H) for $\mathrm{CH}_{2}$, t. $2.9(2 \mathrm{H})$ for $\mathrm{CH}_{2}, 2.4$ for $\mathrm{NH}, 8.7$ for $\mathrm{NH}_{2}, 10.8$ for $\left.\mathrm{NH}\right)$. Elemental analysis found \% C 37.10(37.95), H 6.12(6.37), N 34.85(35.41) calculated for $\mathrm{C}_{5} \mathrm{H}_{10} \mathrm{~N}_{4} \mathrm{~S}$.

2.3. Synthesis of the Complexes. Metal salts $(5 \mathrm{mmol})$ in hot ethanol $(20 \mathrm{~mL})$ were mixed with hot ethanolic solution of the ligand $(10 \mathrm{mmol})$ and refluxed for 4 hours on a water bath; on cooling the contents, the colored complexes separated out in each case. The product was filtered, washed with cold $50 \%$ ethanol, and dried in vacuum over $\mathrm{P}_{4} \mathrm{O}_{10}$. Purity of the complexes was checked by thin layer chromatography (TLC).

2.4. Study of Complex Formation in Solution. The complexes of the ligand with metal ions were studied in DMF, in order to determine the $\mathrm{M}: \mathrm{L}$ ratio in the complex following the molar ratio method. A series of solutions were prepared having a constant concentration $\left(10^{-3} \mathrm{M}\right)$ of the metal ion and

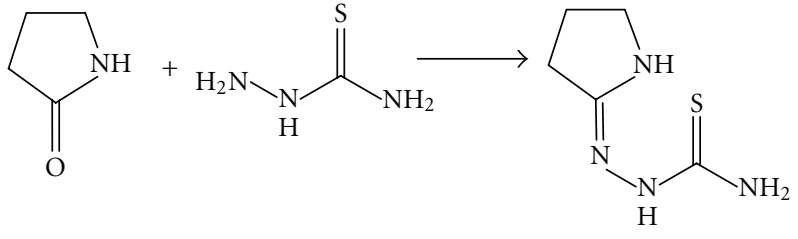

Ligand

SCHEMe 1

(L). The $\mathrm{M}: \mathrm{L}$ ratio was determined from the relationship between the absorption of light and the molar ratio of $\mathrm{M}: \mathrm{L}$. The results of complexes formation in solution were listed in Table 1.

2.5. The Biological Activity for the Ligand and Its Complexes. All tests with the microorganisms were obtained from the Biotechnology Division, Department of Applied Science, University of Technology, which were as follows: Escherichia coli, Klebsiella pneumoniae, Proteus vulgaris, Pseudomonas aeruginosa, and Staphylococcus aureus. Antibacterial activities of the ligand and the soluble complexes were evaluated by the disc diffusion technique [13]. Filter paper (Whatman no. 4) discs (6 mm diameter) were soaked in a solution of the test compounds of $10^{-2} \times 5 \mathrm{mg} \mathrm{mL}^{-1}$ concentration in DMF and placed on nutrient agar plates after drying to remove the solvent. The inhibition zones were measured after $24 \mathrm{~h}$. DMF was used as control. The results are shown in Figure 2.

\section{Results}

General. The complexes were synthesized by reacting ligand with the metal ions in 1:2 molar ratio in ethanolic medium.

3.1. Infrared Spectroscopy. A study and comparison of infrared spectra of free ligand and its metal complexes (Table 2) infers that the ligand behaves as neutral bidentate and its metals are coordinated through $\mathrm{N}$ and $\mathrm{S}$ of the thioketo group (Figure 1).

Strong bands in the 3396 and $3275 \mathrm{~cm}^{-1}$ regions were observed and attributed to $\mathrm{N}-\mathrm{H}$ vibrations in the ligand. 


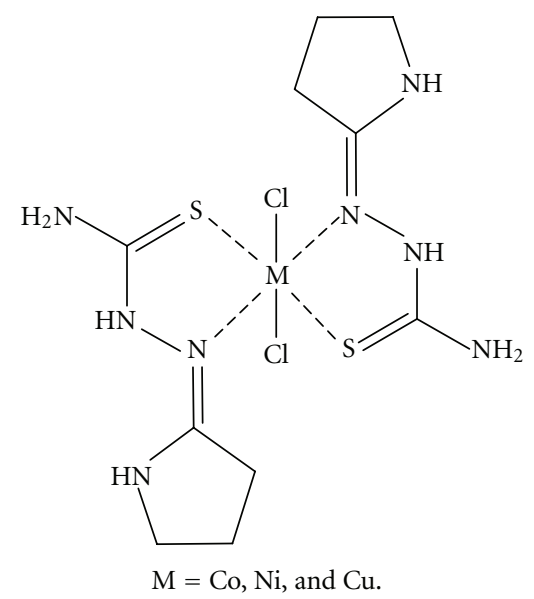

FIGURE 1: Structures of the complexes.

The negligible effect on these frequencies after complexation precludes the possibility of complexation at this group. The absorption at $1600 \mathrm{~cm}^{-1}$ in free ligand can be attributed to $(\mathrm{C}=\mathrm{N})$ stretching vibration of imine nitrogen, which is in a good agreement with previous observations. On complexation, this frequency was observed to be shifted to a lower wave number (Table 2). These observations suggest the involvement of unsaturated nitrogen atoms of the azomethine groups in bonding with the metal ions. Coordination of sulfur with the metal ion would result in the displacement of electrons towards the latter, thus resulting in the weakening of the $(\mathrm{C}=\mathrm{S})$ bond. Hence, on complexation $(\mathrm{C}=\mathrm{S})$ stretching vibrations should decrease and those of $(\mathrm{C}-$ $\mathrm{N})$ should increase. The IR spectral bands in the ligand are practically unchanged in the complexes but show some new bands with medium to weak intensity in the $520-440 \mathrm{~cm}^{-1}$ region tentatively assigned to $(\mathrm{M}-\mathrm{N})$ and $(\mathrm{M}-\mathrm{S}) .(\mathrm{M}-\mathrm{Cl})$ is tentatively assigned in the $360-350 \mathrm{~cm}^{-1}$ region $[14,15]$.

3.2. Magnetic Susceptibility. At room temperature, all the complexes under study show the magnetic moment in the range of 2.1-4.7 B.M. corresponding with the unpaired electrons. The magnetic moment of $\mathrm{Co}$ (II) complex is $4.1 \mathrm{BM}$ showing that the $\mathrm{Co}$ (II) complex is typically a high spin complex and having octahedral structure [16]. For Ni(II) complex, the observed magnetic moment value is $3.0 \mathrm{BM}$ which is well within the expected range for $\mathrm{Ni}(\mathrm{II})$ complex with octahedral stereochemistry (2.83-4.0 BM). The magnetic moment for $\mathrm{Cu}$ (II) complex is 2.0 BM. The reported values for the $\mathrm{Cu}$ (II) complex have no major spin orbital interactions $(1.75-2.20 \mathrm{BM})[16,17]$. Thus the present $\mathrm{Cu}$ (II) complex is without any spin orbital interaction with octahedral geometry. In octahedral $\mathrm{Cu}(\mathrm{II})$ complex, the ground state is $2 \mathrm{Eg}$, and large spin orbital contribution to the magnetic moment is expected.

\section{UV-Visible Spectroscopy}

4.1. Cobalt(II) Complexes. The electronic spectra of $\mathrm{Co}$ (II) complex recorded in DMF solution display three absorption

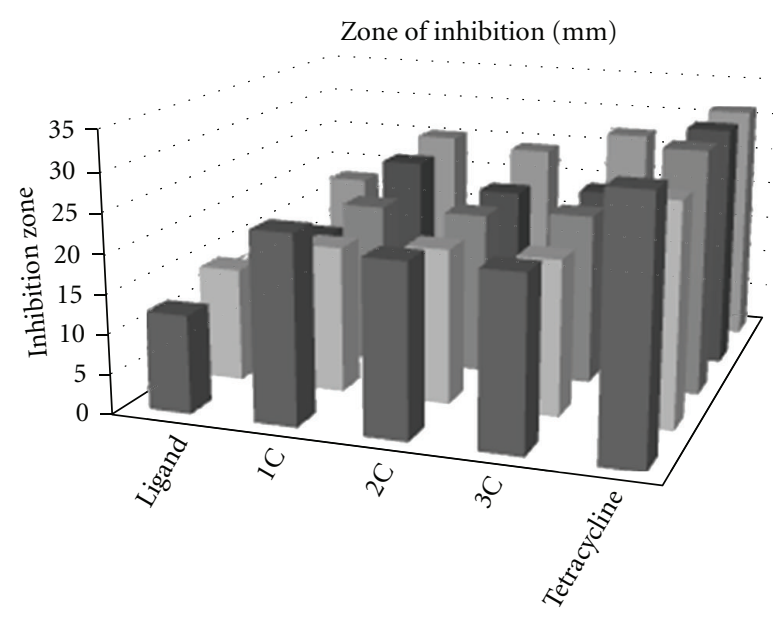

Compounds

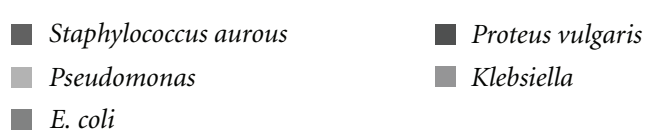

FIgure 2: Antibacterial activity of the ligand and its metal complexes.

bands at 8100,16500 , and $22000 \mathrm{~cm}^{-1}$ corresponding to the following transitions, respectively: ${ }^{4} \mathrm{~T}_{1 \mathrm{~g}(\mathrm{~F})} \rightarrow{ }^{4} \mathrm{~T}_{2 \mathrm{~g}(\mathrm{~F})}$, ${ }^{4} \mathrm{~T}_{1 \mathrm{~g}(\mathrm{~F})} \rightarrow{ }^{4} \mathrm{~A}_{2 \mathrm{~g}(\mathrm{~F})}$, and ${ }^{4} \mathrm{~T}_{1 \mathrm{~g}(\mathrm{~F})} \rightarrow{ }^{4} \mathrm{~T}_{1 \mathrm{~g}(\mathrm{P})}$. This shows that these complexes have octahedral geometry.

4.2. Nickel(II) Complexes. The electronic spectra of the $\mathrm{Ni}$ (II) complex show absorption bands at 9000, 13000, and $24000 \mathrm{~cm}^{-1}$ and may be assigned to the transitions ${ }^{3} \mathrm{~A}_{2} \mathrm{~g} \rightarrow$ ${ }^{3} \mathrm{~T}_{2} \mathrm{~g},{ }^{3} \mathrm{~A}_{2} \mathrm{~g} \rightarrow{ }^{3} \mathrm{~T}_{\lg (\mathrm{F})}$, and ${ }^{3} \mathrm{~A}_{2 \mathrm{~g}(\mathrm{~F})} \rightarrow{ }^{3} \mathrm{~T}_{\mathrm{lg}(\mathrm{P})}$ corresponding with an octahedral geometry.

4.3. Copper(II) Complex. The Cu(II) complex under study displays absorption bands 13400 and $16000 \mathrm{~cm}^{-1}$. These bands were assigned to the following transitions from a distorted octahedral geometry [18]: ${ }^{2} \mathrm{~B}_{1} \mathrm{~g} \rightarrow{ }^{2} \mathrm{~A}_{1} \mathrm{~g},{ }^{2} \mathrm{~B}_{1} \mathrm{~g} \rightarrow$ ${ }^{2} \mathrm{~B}_{2} \mathrm{~g}$.

4.4. Stereo Suggested Structures of Complexes. According to the above-mentioned data (spectra, molar conductance, molar ratio, and magnetic properties), the proposed structures of completes were shown as in Figure 1.

\section{Biological Activity}

It is known that chelation tends to make the ligand act as more powerful and potent bactericidal agents, thus killing more of the bacteria than the ligand. It is observed that, in a complex, the positive charge of the metal is partially shared with the donor atoms present in the ligands, and there may be $\pi$-electron delocalization over the whole chelate [19]. This increases the lipophilic character of the metal chelate and favours its permeation through the lipoid layer of the bacterial membranes. The increased lipophilic character of these complexes seems to be the reason of their enhanced 
TABLE 3: Bond lengths of the ligand.

\begin{tabular}{lcccccccc}
\hline Bond & Actual & Optimal & Bond & Actual & Optimal & Bond & Actual & Optimal \\
\hline $\mathrm{N}(2)-\mathrm{H}(11)$ & 1.0117 & 1.0120 & $\mathrm{C}(8)-\mathrm{H}(15)$ & 1.1188 & 1.1130 & $\mathrm{~N}(5)-\mathrm{H}(13)$ & 0.9906 & 1.0120 \\
$\mathrm{H}(20)-\mathrm{C}(10)$ & 1.1242 & 1.1130 & $\mathrm{C}(9)-\mathrm{C}(8)$ & 1.5256 & 1.5230 & $\mathrm{H}(12)-\mathrm{N}(5)$ & 0.9929 & 1.0120 \\
$\mathrm{C}(10)-\mathrm{H}(19)$ & 1.1246 & 1.1130 & $\mathrm{C}(7)-\mathrm{N}(1)$ & 1.3204 & 1.2600 & $\mathrm{C}(3)-\mathrm{N}(5)$ & 1.3652 & 1.3690 \\
$\mathrm{H}(18)-\mathrm{C}(9)$ & 1.1167 & 1.1130 & $\mathrm{C}(7)-\mathrm{C}(8)$ & 1.5251 & 1.4970 & $\mathrm{C}(3)-\mathrm{S}(4)$ & 1.6285 & 1.5760 \\
$\mathrm{C}(9)-\mathrm{H}(17)$ & 1.1169 & 1.1130 & $\mathrm{H}(14)-\mathrm{N}(6)$ & 0.9976 & 1.0500 & $\mathrm{~N}(2)-\mathrm{C}(3)$ & 1.4145 & 1.3690 \\
$\mathrm{C}(10)-\mathrm{C}(9)$ & 1.5399 & 1.5230 & $\mathrm{C}(10)-\mathrm{N}(6)$ & 1.4571 & 1.4700 & $\mathrm{~N}(1)-\mathrm{N}(2)$ & 1.3414 \\
$\mathrm{C}(8)-\mathrm{H}(16)$ & 1.1188 & 1.1130 & $\mathrm{C}(7)-\mathrm{N}(6)$ & 1.4224 & 1.4620 & & \\
\hline
\end{tabular}

TABLE 4: Bond angles of the ligand.

\begin{tabular}{|c|c|c|c|c|c|}
\hline Angle & Actual & Optimal & Angle & Actual & Optimal \\
\hline $\mathrm{H}(20)-\mathrm{C}(10)-\mathrm{H}(19)$ & 108.0742 & 109.4000 & $\mathrm{C}(7)-\mathrm{C}(8)-\mathrm{H}(15)$ & 110.1767 & 109.4100 \\
\hline $\mathrm{H}(20)-\mathrm{C}(10)-\mathrm{C}(9)$ & 110.8390 & 109.4100 & $\mathrm{C}(7)-\mathrm{C}(8)-\mathrm{C}(9)$ & 105.3224 & 109.5000 \\
\hline $\mathrm{H}(20)-\mathrm{C}(10)-\mathrm{N}(6)$ & 107.3801 & & $\mathrm{~N}(1)-\mathrm{C}(7)-\mathrm{C}(8)$ & 128.1179 & 115.1000 \\
\hline $\mathrm{H}(19)-\mathrm{C}(10)-\mathrm{C}(9)$ & 110.4255 & 109.4100 & $\mathrm{~N}(1)-\mathrm{C}(7)-\mathrm{N}(6)$ & 121.7403 & 126.0000 \\
\hline $\mathrm{H}(19)-\mathrm{C}(10)-\mathrm{N}(6)$ & 111.8302 & & $\mathrm{C}(8)-\mathrm{C}(7)-\mathrm{N}(6)$ & 110.0955 & 125.3000 \\
\hline $\mathrm{C}(9)-\mathrm{C}(10)-\mathrm{N}(6)$ & 108.2648 & & $\mathrm{C}(10)-\mathrm{N}(6)-\mathrm{H}(14)$ & 115.3567 & \\
\hline $\mathrm{H}(18)-\mathrm{C}(9)-\mathrm{H}(17)$ & 108.0210 & 109.4000 & $\mathrm{C}(7)-\mathrm{N}(6)-\mathrm{H}(14)$ & 116.0931 & 118.0000 \\
\hline $\mathrm{H}(18)-\mathrm{C}(9)-\mathrm{C}(10)$ & 110.5216 & 109.4100 & $\mathrm{C}(7)-\mathrm{N}(6)-\mathrm{C}(10)$ & 109.1525 & \\
\hline $\mathrm{H}(18)-\mathrm{C}(9)-\mathrm{C}(8)$ & 111.1762 & 109.4100 & $\mathrm{H}(12)-\mathrm{N}(5)-\mathrm{H}(13)$ & 119.3842 & 118.8000 \\
\hline $\mathrm{C}(10)-\mathrm{C}(9)-\mathrm{H}(17)$ & 110.4261 & 109.4100 & $\mathrm{C}(3)-\mathrm{N}(5)-\mathrm{H}(13)$ & 123.4115 & \\
\hline $\mathrm{H}(17)-\mathrm{C}(9)-\mathrm{C}(8)$ & 110.9742 & 109.4100 & $\mathrm{H}(12)-\mathrm{N}(5)-\mathrm{C}(3)$ & 117.1111 & \\
\hline $\mathrm{C}(10)-\mathrm{C}(9)-\mathrm{C}(8)$ & 105.7415 & 109.5000 & $\mathrm{~N}(5)-\mathrm{C}(3)-\mathrm{S}(4)$ & 122.0027 & 124.3000 \\
\hline $\mathrm{H}(15)-\mathrm{C}(8)-\mathrm{H}(16)$ & 108.4617 & 109.4000 & $\mathrm{~N}(2)-\mathrm{C}(3)-\mathrm{N}(5)$ & 120.9560 & 120.0000 \\
\hline $\mathrm{C}(9)-\mathrm{C}(8)-\mathrm{H}(16)$ & 111.3872 & 109.4100 & $\mathrm{~N}(2)-\mathrm{C}(3)-\mathrm{S}(4)$ & 116.9829 & 124.3000 \\
\hline $\mathrm{C}(7)-\mathrm{C}(8)-\mathrm{H}(16)$ & 110.1951 & 109.4100 & $\mathrm{C}(3)-\mathrm{N}(2)-\mathrm{H}(11)$ & 112.0942 & 117.4000 \\
\hline $\mathrm{C}(9)-\mathrm{C}(8)-\mathrm{H}(15)$ & 111.2857 & 109.4100 & $\mathrm{~N}(1)-\mathrm{N}(2)-\mathrm{H}(11)$ & 120.3309 & \\
\hline $\mathrm{C}(10)-\mathrm{C}(9)-\mathrm{H}(17)$ & 110.4261 & 109.4100 & $\mathrm{~N}(1)-\mathrm{N}(2)-\mathrm{C}(3)$ & 122.2156 & \\
\hline
\end{tabular}

potent antibacterial activity. There are other factors which also increase the activity, which are solubility, conductivity, and bond length between the metal and the ligand.

\section{Stability Study}

These data show that the atomic charge was affected by the presence of substituent of rings as shown in Tables 3, 4, and 5. As a reference compound, the unsubstituted ligand (Figure 3), the data for minimized geometry, and the $3 \mathrm{~d}$ geometrical structure are shown in (Figure 3).

\section{Discussion}

All the solid complexes are stable in air. The metal complexes are soluble in DMF and DMSO. Table 1 shows the colors, elemental analyses, and molar conductivities of the cobalt(II), nickel(II), and copper(II) complexes. Thiosemicarbazones can coordinate with metal ions as neutral ligand. The $\mathrm{C}, \mathrm{H}$, and $\mathrm{N}$ data indicate that the complexes of neutral ligand are coordinated to the metal ion, and the other coordination positions were occupied by chlorine, as confirmed by the IR spectra of the complexes. The antibacterial screening (Figure 2) indicates that the complexes inhibit the growth

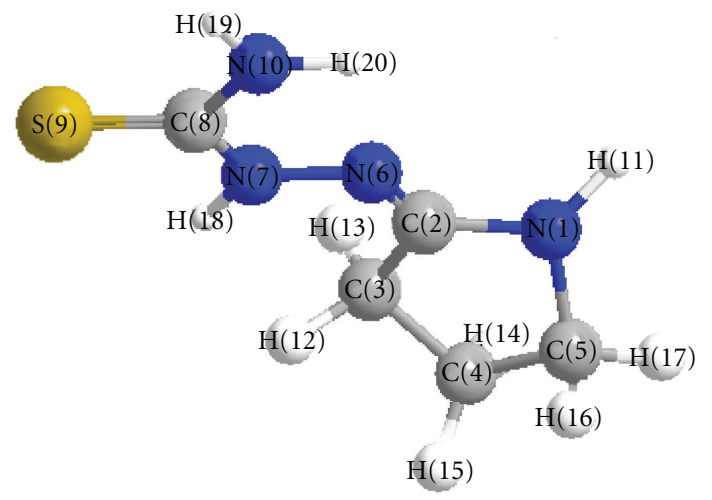

FIgURE 3: The 3d-geometrical structure for the ligand.

of Staphylococcus aurous and Klebsiella, whereas other complexes have less activity against other tested bacteria. The theoretical data obtained show that the heat of formation is $52.61737 \mathrm{kcal} / \mathrm{mole}$, and the highest atomic charge (Table 5) in ligand molecule is at [S4-0.696] and the next charge value is at $[\mathrm{N} 1-0.431]$. These data show clearly that these atoms are the most reactive toward the bonding with the metal. 
TABLE 5: Atomic charge of the ligand.

\begin{tabular}{llllllll}
\hline Charges & Atoms & Charges & Atoms & Charges & Atoms & Charges & Atoms \\
\hline $\mathrm{N}-0.431$ & {$[\mathrm{~N}(1)]$} & $\mathrm{N} 0.081$ & {$[\mathrm{~N}(6)]$} & $\mathrm{H} 0.068$ & {$[\mathrm{H}(11)]$} & $\mathrm{H} 0.040$ & {$[\mathrm{H}(16)]$} \\
$\mathrm{N} 0.263$ & {$[\mathrm{~N}(2)]$} & $\mathrm{C} 0.222$ & {$[\mathrm{C}(7)]$} & $\mathrm{H} 0.101$ & {$[\mathrm{H}(12)]$} & $\mathrm{H} 0.031$ & {$[\mathrm{H}(17)]$} \\
$\mathrm{C} 0.233$ & {$[\mathrm{C}(3)]$} & $\mathrm{C}-0.122$ & {$[\mathrm{C}(8)]$} & $\mathrm{H} 0.104$ & {$[\mathrm{H}(13)]$} & $\mathrm{H} 0.028$ & {$[\mathrm{H}(18)]$} \\
$\mathrm{S}-0.696$ & {$[\mathrm{~S}(4)]$} & $\mathrm{C}-0.066$ & {$[\mathrm{C}(9)]$} & $\mathrm{H} 0.091$ & {$[\mathrm{H}(14)]$} & $\mathrm{H} 0.011$ & {$[\mathrm{H}(19)]$} \\
$\mathrm{N}-0.049$ & {$[\mathrm{~N}(5)]$} & $\mathrm{C} 0.036$ & {$[\mathrm{C}(10)]$} & $\mathrm{H} 0.038$ & {$[\mathrm{H}(15)]$} & $\mathrm{H} 0.018$ & {$[\mathrm{H}(20)]$} \\
\hline
\end{tabular}

The determined bond angle (Table 4) and 3D-geometrical (Figure 3) structure indicate that this molecule is planar. The stability for the prepared complexes was studied theoretically by the density function theory (DFT). The total energy for the complexes was calculated, and it was shown that the copper complex is the most stable, and the cobalt complex is the least stable as follow: $\mathrm{Cu}$-complex $>\mathrm{Ni}$-complex $>\mathrm{Co}-$ complex.

\section{Conclusion}

Based on the reported results, it may be concluded that ligand acts as bidentate neutral ligand, coordinating through one of the nitrogen atoms and the sulfur. In the present work, which facilitates the formation of six member rings, this shifts the nitrogen atom of the other ring away from the coordination site. In the present investigations, all the complexes are found to be mononuclear, based on the FT-IR spectral data. The coordination number six is attained by coordination with the two bidentate ligand molecules and two chloride atoms. Based on the physicochemical and the spectral studies the tentative structures proposed for the complexes are shown in Figure 1.

\section{References}

[1] J. S. Casas, M. S. García-Tasende, and J. Sordo, "Main group metal complexes of semicarbazones and thiosemicarbazones. A structural review," Coordination Chemistry Reviews, vol. 209, no. 1, pp. 197-261, 2000.

[2] D. Mishra, S. Naskar, M. G.B. Drew, and S. K. Chattopadhyay, "Synthesis, spectroscopic and redox properties of some ruthenium(II) thiosemicarbazone complexes: structural description of four of these complexes," Inorganica Chimica Acta, vol. 359, no. 2, pp. 585-592, 2006.

[3] I. Kizilcikli, B. Ülküseven, Y. Daşdemir, and B. Akkurt, “Zn(II) and $\mathrm{Pd}(\mathrm{II})$ complexes of thiosemicarbazone-S-alkyl esters derived from 2/3-formylpyridine," Synthesis and Reactivity in Inorganic and Metal-Organic Chemistry, vol. 34, no. 4, pp. 653 665, 2004 .

[4] N. K. Singh, S. B. Singh, and A. Shrivastav, "Spectral, magnetic and biological studies of 1,4-dibenzoyl-3-thiosemicarbazide complexes with some first row transition metal ions," Proceedings of the Indian Academy of Sciences, vol. 113, no. 4, pp. 257273, 2001.

[5] O. E. Offiong and S. Martelli, "Stereochemistry and antitumour activity of platinum metal complexes of 2-acetylpyridine thiosemicarbazones," Transition Metal Chemistry, vol. 22, no. 3, pp. 263-269, 1997.
[6] E. Labisbal, K. D. Haslow, A. Sousa-Pedrares, J. ValdésMartínez, S. Hernández-Ortega, and D. X. West, "Copper(II) and nickel(II) complexes of 5-methyl-2-hydroxyacetophenone N(4)-substituted thiosemicarbazones," Polyhedron, vol. 22, no. 20, pp. 2831-2837, 2003.

[7] R. V. Singh, N. Fahmi, and M. K. Biyala, "Coordination behavior and biopotency of $\mathrm{N}$ and $\mathrm{S} / \mathrm{O}$ donor ligands with their Palladium(II) and Platinum(II) complexes," Journal of the Iranian Chemical Society, vol. 2, no. 1, pp. 40-46, 2005.

[8] S. Chandra, Sangeetika, and A. Rathi, "Magnetic and spectral studies on copper(II) complexes of N-O and N-S donor ligands," Journal of Saudi Chemical Society, vol. 5, no. 2, pp. 175-182, 2001.

[9] N. Raman, A. Kulandaisamy, A. Shunmugasundaram, and K. Jeyasubramanian, "Synthesis, spectral, redox and antimicrobial activities of Schiff base complexes derived from 1-phenyl-2,3-dimethyl-4-aminopyrazol-5-one and acetoacetanilide," Transition Metal Chemistry, vol. 26, no. 1-2, pp. 131135, 2001.

[10] N. Raman, A. Kulandaisamyand, and K. Jeyasubramanian, "Synthesis, spectral, redox, and antimicrobial activity of Schiff base transition metal(II) complexes derived from 4-aminoantipyrine and benzil," Synthesis and Reactivity in Inorganic and Metal-Organic Chemistry, vol. 32, no. 9, pp. 1583-1610, 2002.

[11] L. Singh, D. K. Sharma, U. Singh, and A. Kumar, "Synthesis and spectral studies of $\mathrm{Cu}(\mathrm{II})$ coordination compounds of 4 [N-(cinnamalidene) amino] antipyrine semicarbazone," Asian Journal of Chemistry, vol. 16, no. 2, pp. 577-580, 2004.

[12] N. Raman, C. Thangaraja, and S. Johnsonraja, "Synthesis, spectral characterization, redox and antimicrobial activity of Schiff base transition metal(II) complexes derived from 4-aminoantipyrine and 3-salicylideneacetylacetone," Central European Journal of Chemistry, vol. 3, no. 3, pp. 537-555, 2005.

[13] A. L. Banty, The Antimicrobial Susceptibility Test; Principles and Practice, Lea and Febiger, Philadelphia, Pa, USA, 1979.

[14] R. K. Agarwal and S. Prasad, "Synthesis and spectral investigations of some platinum metals ions coordination compounds of $4\left[\mathrm{~N}\right.$-(furan-2 ${ }^{\prime}$-carboxalidene)amino]antipy rine thiosemicarbazone and $4\left[\mathrm{~N}-\left(3^{\prime}, 4^{\prime}, 5^{\prime}\right.\right.$-trimethoxybenzalidene) amino] antipyrine thiosemicarbazone," Turkish Journal of Chemistry, vol. 29, no. 3, pp. 289-297, 2005.

[15] S. Chandra and R. Kumar, "Synthesis and spectral studies on mononuclear complexes of chromium(III) and manganese(II) with 12-membered tetradentate N2O2, N2S2 and N4 donor macrocyclic ligands," Transition Metal Chemistry, vol. 29, no. 3, pp. 269-275, 2004.

[16] S. Chandra and K. B. Pandeya, "Oxovanadium(IV) complexes of cyclohexanone semicarbazone and cyclohexanone thiosemicarbazone," Transition Metal Chemistry, vol. 6, no. 2, pp. 110-113, 1981.

[17] V. Reddy, N. Patil, T. Reddy, and S. D. Angadi, "Synthesis, characterization and biological activities of $\mathrm{Cu}(\mathrm{II}), \mathrm{Co}(\mathrm{II})$, $\mathrm{Ni}(\mathrm{II}), \mathrm{Mn}(\mathrm{II})$ and $\mathrm{Fe}(\mathrm{III})$ complexes with Schiff base derived 
from 3-(4-chlorophenoxymethyl)-4-amino-5-mercapto-1,2, 4-triazole," E-Journal of Chemistry, vol. 5, no. 3, pp. 529-538, 2008.

[18] A. B. P. Lever, Inorganic Electronic Spectroscopy, Elsevier, New York, NY, USA, 1984.

[19] A. Wissner, D. M. Berger, D. H. Boschelli et al., "4-anilino6,7-dialkoxyquinoline-3-carbonitrile inhibitors of epidermal growth factor receptor kinase and their bioisosteric relationship to the 4-anilino-6,7-dialkoxyquinazoline inhibitors," Journal of Medicinal Chemistry, vol. 43, no. 17, pp. 3244-3256, 2000. 


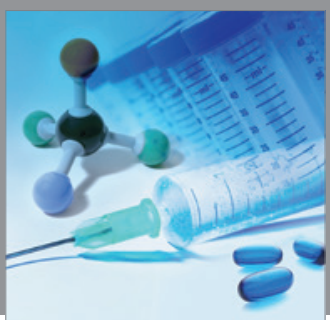

International Journal of

Medicinal Chemistry

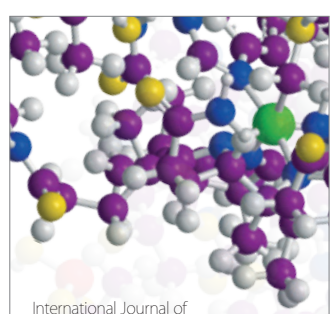

Carbohydrate Chemistry

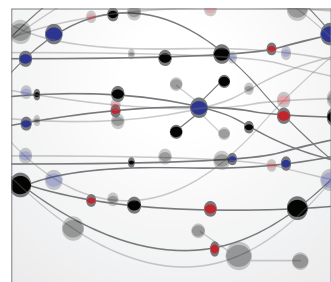

The Scientific World Journal
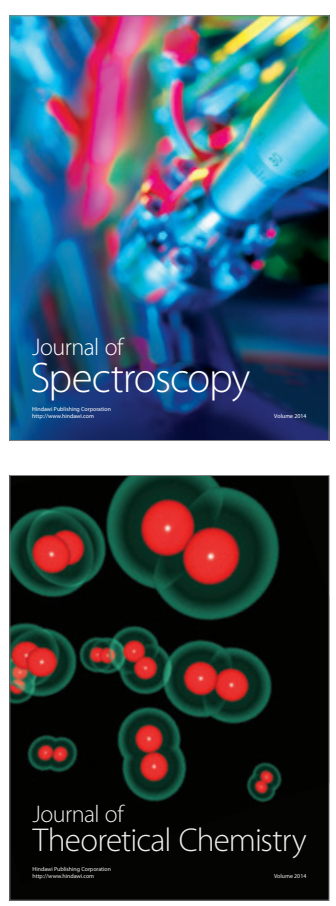
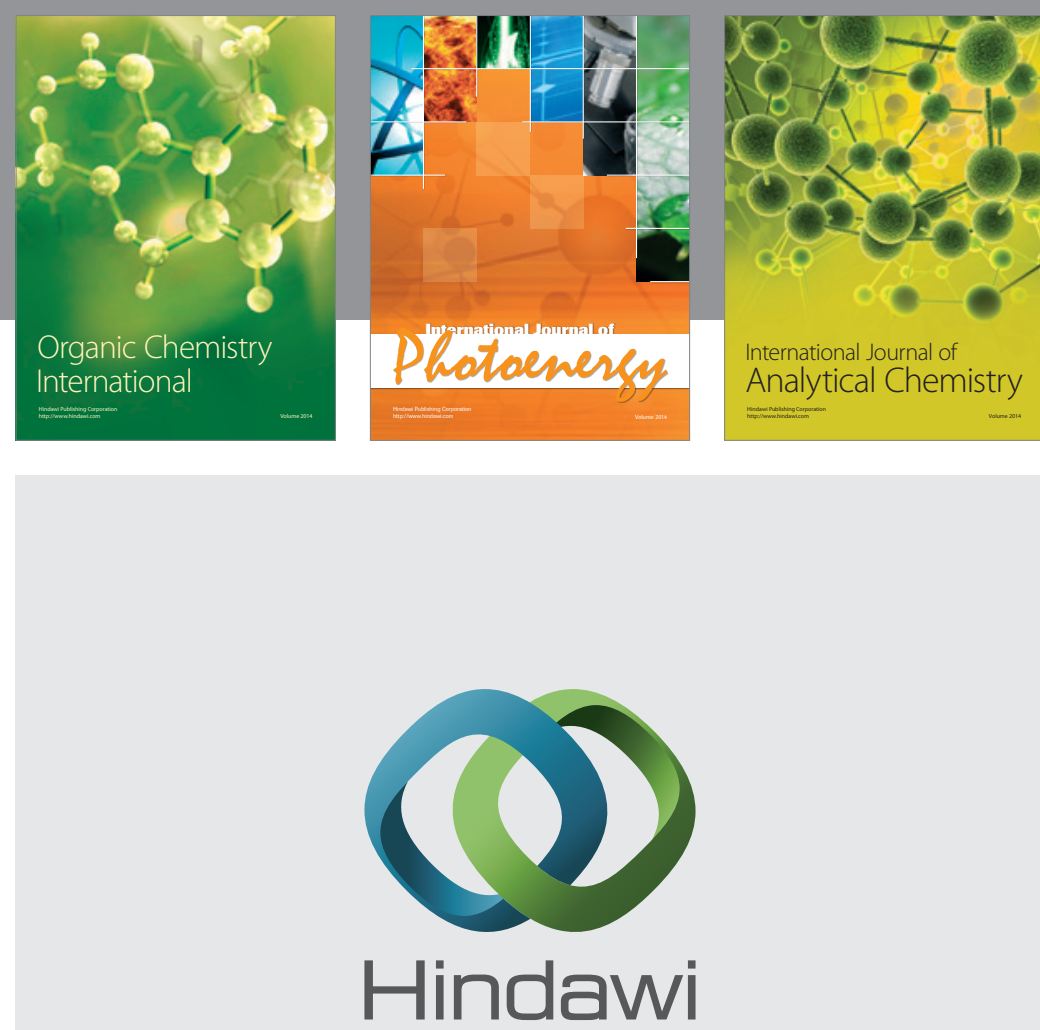

Submit your manuscripts at

http://www.hindawi.com
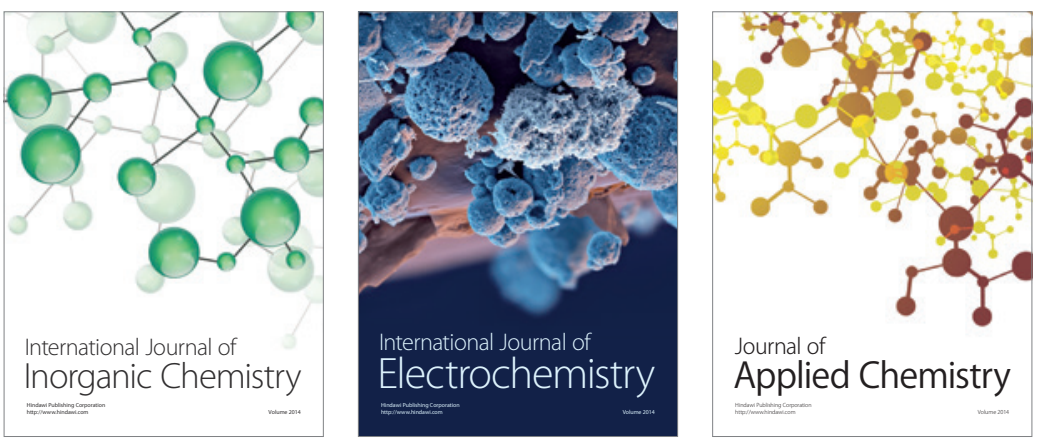

Journal of

Applied Chemistry
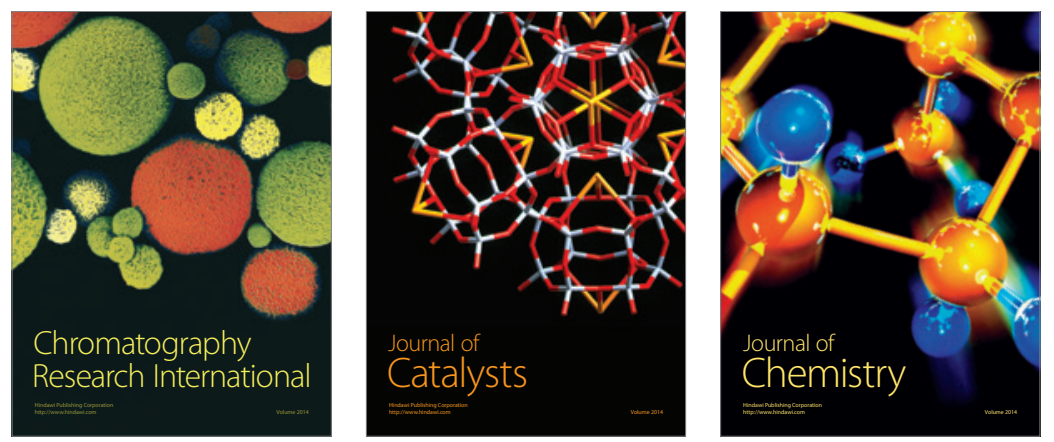
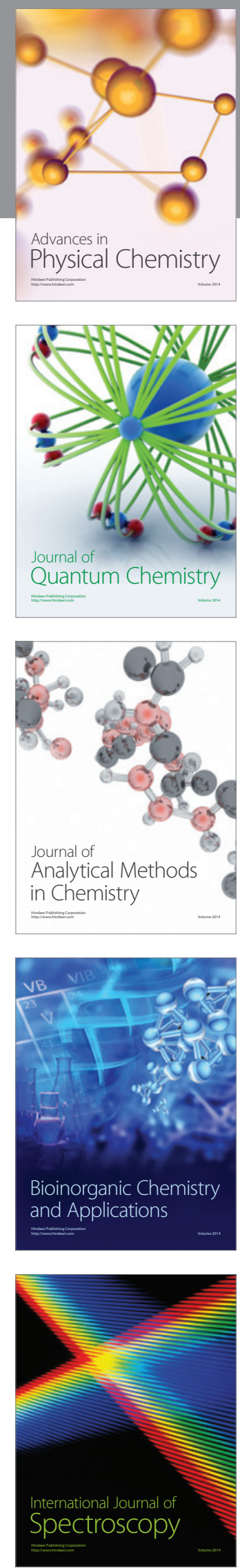